Araştırma Makalesi - Research Article

\title{
Potansiyel MAO-B İnhibitörü Olarak Propargil Yan Zinciri İçeren Yeni Bileşiklerin Sentezi ve Karakterizasyonu
}

\author{
Derya Osmaniye $^{1 *}$, Yusuf Özkay ${ }^{2}$
}

Revize / Revised: 09/09/2020
Kabul / Accepted: 26/11/2020

\section{öZ}

$\mathrm{Bu}$ çalışma kapsamında, propargil grubunun Monoaminoksidaz-B (MAO-B) enzimi üzerindeki potansiyel inhibitör etkinliği dikkate alınarak bazı yeni propargil grubu içeren bileşikler sentezlenmiştir. Sentez çalışmalarında, 2- klorobenzimidazol $\mathrm{NaH}$ varlığında propargil bromür ile reaksiyona sokulmuş bileşik 1 elde edilmiştir. Bileşik 1 çeşitli benzilamin türevleri ile potasyum karbonat katalizörlüğünde muamele edilerek sonuç ürünlerine (2a-2c) ulaşılmıştır. Elde edilen bileşiklerin yapıları ${ }^{1} \mathrm{HNMR}$ ve ${ }^{13} \mathrm{C}-\mathrm{NMR}$ ve HRMS spektroskopik yöntemleri ile doğrulanmıştır. Sentezlenen bileşiklerin MAO enzimleri üzerindeki etkileri in-vitro şartlarda florimetrik yöntem kullanılarak araştıılmıştır. Yapılan aktivite çalışmaları sonucunda sentezlenen bileşiklerin MAO enzimlerini değişen düzeylerde inhibe ettiği tespit edilmiştir.

Anahtar Kelimeler- Propargil, Benzimidazol, NMR, Monoamin Oksidaz, Parkinson Hastalı̆̆ı

1*Sorumlu yazar iletişim: dosmaniye@anadolu.edu.tr (https://orcid.org/0000-0002-0499-436X) Anadolu Üniversitesi, Eczacılık Fakültesi, Farmasötik Kimya Anabilim Dalı, 26470, Eskişehir, Türkiye 2İletișim: yozkay@anadolu.edu.tr (https://orcid.org/ 0000-0001-8815-153X) Anadolu Üniversitesi, Eczacılık Fakültesi, Farmasötik Kimya Anabilim Dalı, 26470, Eskişehir, Türkiye 


\title{
Synthesis and Characterization of New Compounds Including Propargyl Side Chain as Potential MAO-B Inhibitor
}

\begin{abstract}
In this study, some new propargyl derivatives were synthesized considering potential monoamine oxidase-B (MAO-B) inhibition potency of propargyl moiety. In synthesis studies, 2-chlorobenzimidazole was reacted with propargyl bromide in the presence of $\mathrm{NaH}$ and compound 1 was obtained. Compound 1 was treated with various benzylamine derivatives and final products $(2 \mathrm{a}-2 \mathrm{c})$ were gained. Structures of obtained compounds were established by spectroscopic methods. Effects of the synthesized compounds against MAO enzymes were observed by using in-vitro fluorimetric method. Activity studies revealed that synthesis compounds inhibited MAO enzymes to different extends. .
\end{abstract}




\section{INTRODUCTION}

Neurodegenerative disorders (NDs), characterized by temporary and irreparable loss of neuronal cells thought of by the loss of neurons in the brain, represent one of the main causes of death in industrialized countries. Alzheimer's (AD), Parkinson (PD) diseases have attracted great attention among neurodegenerative diseases. The daily activities of individuals with PD disease, which is a neurological disorder, are gradually affected and the quality of life decreases gradually. The disease, which also has a large number of symptoms, is progressive. The affected basal ganglion region, in which the monoamine oxidase B (MAO-B) isoform is mainly responsible for the metabolism of dopamine, is associated with the pathology of this disease. Dopaminergic (DA-ergic) neurons in CNS, which are known to be involved in the control of a number of basic physiological functions including cognitive behavioral, neuroendocrine and motor systems, play an important role in the pathology of neurodegenerative diseases. MAO containing $\mathrm{Cu}^{2+}, \mathrm{Fe}^{2+}$ and phospholipid is a binding enzyme. And thanks to their effects on the methylation of primary amine and secondary and tertiary amine, they are responsible for the main catalytic deamination of monoamines $\left(\mathrm{R}^{-} \mathrm{CH}_{2} \mathrm{NH}_{2}\right)$. Amines catalyzed by the monoamine oxidase (MAO) enzyme family include endogenous amines containing many neurotransmitters, such as dopamine, epinephrine, tyramine, benzylamine, serotonin, norepinephrine and $\beta$-phenyl ethylamine. MAOs have two isoforms. These isoforms have different substrate and inhibitors. In the heterogeneous enzyme, the isoform which chlorgiline inhibited more strongly was named as MAO-A. A selective inhibitor that affects another isoform called MAO-B is Selegiline [1-9].

Parkinsonism is a disease accompanied by tremor, rigidity, bradykinesia, akinesia and postural abnormalities as a clinical syndrome. Parkinson's disease, which has no radical treatment with drugs, was first described by James Parkinson in 1817 as a chronic progressive and degenerative disease of the central nervous system. James Parkinson described the disease as a pulsating paralysis. Parkinsonism is a complex table of symptoms due to cell loss in the motor nuclei of the brain base. What distinguish Parkinson's disease from other variants of parkinsonism are the differences on the pathological basis. These; dopaminergic neurons in substantia nigra are primarily degeneration of pigmented neurons in the brainstem and Lewy bodies detected in surviving cells. Parkinson's disease is the second most common neurodegenerative disease after Alzheimer's. It is effective in genetic factors in the emergence of the disease. Many recent clinical studies have shown that it is effective in the formation of diseases in genetic factors as well as environmental factors. Parkinson's disease starts on average at the age of 50-60 and continues progressively over a period of 10-20 years. Studies conducted in mayo clinic revealed that the risk of Parkinson's disease is $2 \%$ in men and $1.3 \%$ in women. The reason for this difference may be hormonal differences. In addition, environmental factors (especially pesticides used in agriculture), genetic factors and toxins are factors affecting Parkinson's disease in people. Parkinson's disease is a chronic idiopathic disease that develops as a result of the excessive decrease of the neurodilator dopamine in the basal ganglia (especially in the corpus striatum) due to the decreased number of nigrostriatal dopaminergic neurons in the brain. It is a relatively common neurological disease; USA. According to statistics, the number of new cases per year is approximately 20 per 100,000 people. [10-12].

In Parkinson's disease, the dopaminergic neurons of the extrapyramidal system decrease in dopamine level. The balance between the cholinergic and dopaminergic system is disrupted in favor of cholinergic activity. MAO inhibitor drugs are used in the treatment of Parkinson's disease as they increase the level of dopamine by inhibiting the MAO enzyme that oxidizes dopamine. MAOI containing the propargyl group is responsible for the deamination of dopamine, and preferably phenylethylamine and the like, which is responsible for about $80 \%$ of the activity of the MAO enzyme in the brain. It is thought to show antiparkinson activity by raising the level of dopamine in the brain and partly reducing the free oxygen radicals that are involved in the progression of Parkinson's disease. In the treatment of Parkinson's disease, drugs are applied in a certain order. As a rule, there is no need for medication in the early period, when the symptoms of the disease do not disturb the daily life. Selegiline, anticholinergic drugs or amantadine should be tried first in cases that are a little more advanced. If the patient is young or tremors are prominent, anticholinergic drugs are preferred to amantadine. If the disease has advanced and the disease cannot be rehabilitated with the two medicaments mentioned above, it is switched to levadopa or levadopa + dopa decarboxylase inhibitor combination. If necessary, however, MAO B inhibitor selegiline or KOMT inhibitor tolcapone is given. [13]. 
Selegiline is also thought to act by reducing free oxygen radicals that are involved in the progression of Parkinson's disease and are composed of dopamine. Hydrogen peroxide and oxygen radicals are formed at the dopaminergic nerve endings during oxidative deamination of dopamine with MAO. Reduced glutathione (GSH) is converted from GSH peroxidase tar to glutathione disulfide. Hydrogen peroxide and glutathione disulfide are oxidant stress factors leading to the destruction of dopaminergic tips. Selegiline's inhibition of MAOB reduces or eliminates oxidant stress as it slows down these reactions. It also prevents the dopamine from being taken back from the nerve end. It can be used alone for initial therapy in patients. In advanced cases, it is often used with levadopa and decarboxylase inhibitors. The most common side effects are nausea, dry mouth, hypotension, insomnia, confusion and live dreams.

In the current study, a new series containing propargyl side chains in the structure of the selective MAO-B inhibitor selegiline was synthesized to examine their activity against MAO enzyme isotypes to develop safer and stronger MAO-B inhibitors (Figure 1). Benzimidazole ring, which is known to be responsible for many activities, was preferred in the structure. It is also planned to develop a potent MAO inhibitor using benzylamine substituents, an endogenous amine already used as a substrate.

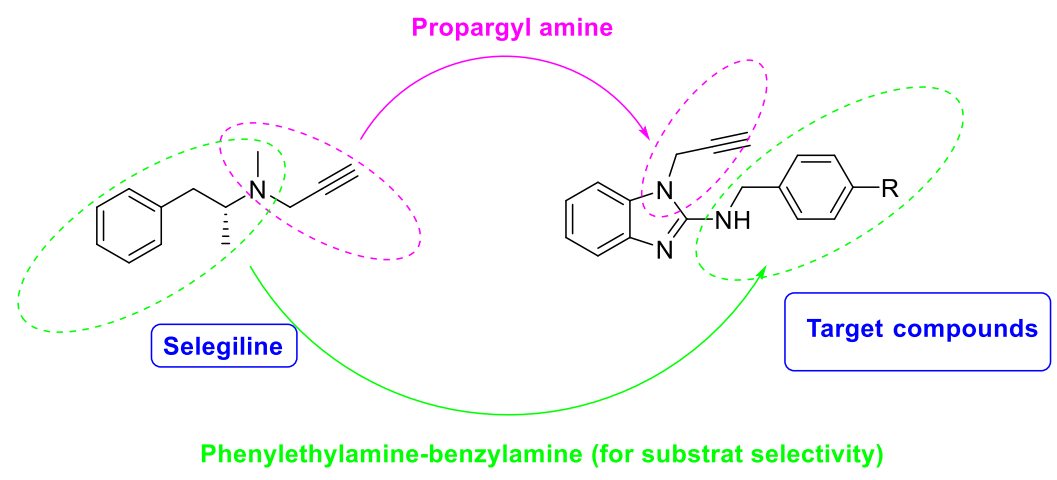

Figure 1. Design of target compounds

\section{MATERIAL AND METHOD}

\section{A. Chemistry}

All chemicals used in the synthesis studies were obtained from Merck Chemicals (Merck KGaA, Darmstadt, Germany) or Sigma-Aldrich Chemicals (Sigma-Aldrich Corp., St. Louis, Mo., USA). A Bruker 300 $\mathrm{MHz}$ and $75 \mathrm{MHz}$ digital FT-NMR spectrometer (Bruker Bioscience, Billerica, MA, USA) in DMSO- $d_{6}$, respectively recorded ${ }^{1} \mathrm{H}$ NMR and ${ }^{13} \mathrm{C}$ NMR spectra. In the NMR spectra splitting patterns were determined recognized as follows: s: singlet; d: doublet; t: triplet; td: triple doublet; m: multiplet. Coupling constants (J) are reported in units of Hertz $(\mathrm{Hz})$. Mass spectra were recorded on an LCMS-IT-TOF (Shimadzu, Kyoto, Japan) by means of ESI method. Silica gel 60 F254 by TLC (Merck KGaA, Darmstadt, Germany) was used to control the purity of the obtained compounds.

Synthesis of 2-Chloro-1-(prop-2-yn-1-yl)-1H-benzo[d]imidazole (1): 2-Chlorobenzimidazole (5g, $0.0328 \mathrm{~mol})$ dissolved in DMF $(10 \mathrm{~mL})$ was interacted with $\mathrm{NaH}(0.98 \mathrm{~g}, 0.041)$. Propargyl bromide $(6 \mathrm{~mL}$, $0.3310 \mathrm{~mol}$ ) was added to this mixture, where mixing of gas was completed for 5 minutes. The reaction content, which was continued for 30 hours at $25{ }^{\circ} \mathrm{C}$, was poured into ice water, the product precipitated, filtered and washed with water, then dried and crystallized from ethanol.

Synthesis of 2-(4-Substitutedbenzylamino)-1-propargyl-1H-benzo[d]imidazole (2a-2c): 2-Chloro-1(prop-2-yn-1-yl)-1H-benzo[d]imidazole $(0.5 \mathrm{~g}, 0.0026 \mathrm{~mol})$, the appropriate benzylamine derivative $(0.00286 \mathrm{~mol})$ and potassium carbonate $(0.0026 \mathrm{~mol}, 0.3588 \mathrm{~g})$ were dissolved in DMF $(5 \mathrm{~mL})$. The final solution 
content, which was stirred under reflux for 24 hours, was terminated by pouring it into ice water. The product taken up by filtration was washed with water, dried and crystallized from ethanol.

N-benzyl-1-(prop-2-yn-1-yl)-1H-benzo[d]imidazol-2-amine (2a : [14] Yield: $81 \%$, FTIR (ATR, $\left.\mathrm{cm}^{-1}\right)$ : $3263(\mathrm{~N}-\mathrm{H}), 1635(\mathrm{C}=\mathrm{C}), 734,698.1 \mathrm{H}-\mathrm{NMR}\left(300 \mathrm{MHz}, \mathrm{DMSO}-d_{6}\right): \delta=2.26(1 \mathrm{H}, \mathrm{s},-\mathrm{CH}), 2.26(2 \mathrm{H}, \mathrm{s}$, methylene), $5.25\left(2 \mathrm{H}, \mathrm{s}\right.$, methylene), $7.02(1 \mathrm{H}, \mathrm{t}, J=7.9 \mathrm{~Hz},-\mathrm{NH}), 7.16\left(1 \mathrm{H}, \mathrm{td}, J_{l}=0.9 \mathrm{~Hz}, J_{2}=7.7 \mathrm{~Hz}\right.$, Benzimidazole-H), 7.27-7.34 (5H, m, Monosubstituebenzene), 7.47 (1H, d, J=8.0 Hz, Benzimidazole-H), 7.53 $\left(1 \mathrm{H}, \mathrm{d}, J=0.9 \mathrm{~Hz}\right.$, Benzimidazole-H), $7.70\left(1 \mathrm{H}, \mathrm{d}, J=7.8 \mathrm{~Hz}\right.$, Benzimidazole-H). ${ }^{13} \mathrm{C}-\mathrm{NMR}(75 \mathrm{MHz}, \mathrm{DMSO}-$ $\left.d_{6}\right): \delta=31.34,46.00,72.29,78.50,103.06,110.71,117.74,117.91,122.21,127.37,128.04,129.20,137.74$, 147.04, 152.34. HRMS (m/z): [M+H] $]^{+}$calcd for $\mathrm{C}_{17} \mathrm{H}_{15} \mathrm{~N}_{3}$ : 262.1339; found: 262.1347.

$N$-(4-chlorobenzyl)-1-(prop-2-yn-1-yl)-1H-benzo[d]imidazol-2-amine (2b): Yield: $75 \%$, FTIR (ATR, $\left.\mathrm{cm}^{-1}\right): 3321(\mathrm{~N}-\mathrm{H}), 1635(\mathrm{C}=\mathrm{C}), 738.1 \mathrm{H}-\mathrm{NMR}\left(300 \mathrm{MHz}, \mathrm{DMSO}-d_{6}\right): \delta=2.24(1 \mathrm{H}, \mathrm{s},-\mathrm{CH}-), 2.25(2 \mathrm{H}, \mathrm{s}$, methylene), $5.24\left(2 \mathrm{H}, \mathrm{s}\right.$, methylene), $7.03(1 \mathrm{H}, \mathrm{t}, J=7.6 \mathrm{~Hz},-\mathrm{NH}), 7.16\left(1 \mathrm{H}, \mathrm{td}, J_{l}=0.9 \mathrm{~Hz}, J_{2}=7.7 \mathrm{~Hz}\right.$, Benzimidazole-H), $7.30(2 \mathrm{H}, \quad \mathrm{d}, \quad J=8.5 \mathrm{~Hz}, \quad 1,4$-Disubstituebenzene), $7.39 \quad(2 \mathrm{H}, \quad \mathrm{d}, \quad J=8.5 \quad \mathrm{~Hz}, \quad 1,4-$ Disubstituebenzene), 7.48 (1H, d, $J=8.0 \mathrm{~Hz}$, Benzimidazole-H), $7.53(1 \mathrm{H}, \mathrm{d}, J=1.2 \mathrm{~Hz}$, Benzimidazole-H), 7.70 $\left(1 \mathrm{H}, \mathrm{d}, J=7.8 \mathrm{~Hz}\right.$, Benzimidazole-H). ${ }^{13} \mathrm{C}-\mathrm{NMR}\left(75 \mathrm{MHz}, \mathrm{DMSO}-d_{6}\right): \delta=31,42,45.35,72.99,79.20,103.17$, 110.72, 117.78, 117.99, 122.24, 129.18, 129.33, 132.69, 136.72, 147.02, 152.24. HRMS (m/z): $[\mathrm{M}+\mathrm{H}]^{+}$calcd for $\mathrm{C}_{17} \mathrm{H}_{14} \mathrm{~N}_{3} \mathrm{Cl}$ : 296.0949; found: 296.0949.

N-(4-methoxybenzyl)-1-(prop-2-yn-1-yl)-1H-benzo[d]imidazol-2-amine (2c): Yield: $79 \%$, FTIR (ATR, $\left.\mathrm{cm}^{-1}\right): 3140(\mathrm{~N}-\mathrm{H}), 1635(\mathrm{C}=\mathrm{C}), 790.1 \mathrm{H}-\mathrm{NMR}\left(300 \mathrm{MHz}, \mathrm{DMSO}-d_{6}\right): \delta=2.26(1 \mathrm{H}, \mathrm{s},-\mathrm{CH}-), 2.27(2 \mathrm{H}, \mathrm{s}$, methylene), 3.70 (3H, s, -methoxy), 5.17 (2H, s, methylene), 6.89 (2H, d, J=8.8 Hz, 1,4-Disubstituebenzene), $7.01(1 \mathrm{H}, \mathrm{t}, J=7.1 \mathrm{~Hz},-\mathrm{NH}), 7.16\left(1 \mathrm{H}, \mathrm{td}, J_{l}=1.1 \mathrm{~Hz}, J_{2}=7.3 \mathrm{~Hz}\right.$, Benzimidazole-H), $7.26(2 \mathrm{H}, \mathrm{d}, J=8.7 \mathrm{~Hz}, 1,4-$ Disubstituebenzene), 7.47-7.50 (2H, m, Benzimidazole-H), 7.69 (1H, d, J=7.7 Hz, Benzimidazole-H). ${ }^{13} \mathrm{C}-\mathrm{NMR}$ $\left(75 \mathrm{MHz}, \mathrm{DMSO}-d_{6}\right): \delta=31.04,45.56,55.52,73.52,78.57,102.96,110.67,114.54,117.74,117.85,122.18$, 128.96, 129.66, 147.07, 152.33, 159.16. HRMS (m/z): $[\mathrm{M}+\mathrm{H}]^{+}$calcd for $\mathrm{C}_{18} \mathrm{H}_{17} \mathrm{~N}_{3} \mathrm{O}$ : 292.1444; found: 292.1434.

\section{B. MAO Inhibitory Assay}

The effects of synthesis compounds on MAO-A and MAO-B enzymes were measured fluorimetrically in vitro using a microplate reader. Experiments were carried out in 96-well plates. Human MAO-A and MAO-B enzymes (Sigma-Aldrich, Germany) stock solutions were prepared in $0.1 \mathrm{M}$ phosphate buffer at a concentration of $5 \mathrm{mg} / \mathrm{mL}$. In fluorimetric measurements, MAO-A stock solution was used by diluting with buffer solution to $0.006 \mathrm{mg} / \mathrm{mL}$ and MAO B stock solution was diluted with buffer solution to $0.015 \mathrm{mg} / \mathrm{mL}$. In enzymatic reactions, kynuramin stock solution was used as fluorimetric reagent at a concentration of $25 \mathrm{mM}$. In fluorimetric measurements, the kynuramin solution was used to dilute to $40 \mu \mathrm{M}$ concentration with buffer solution for MAO-A activity, and the kynuramin solution was diluted with buffer solution to $20 \mu \mathrm{M}$ concentration for MAO B activity. Test compounds were added to microplates at $8 \mu$ dilution concentrations, using $2 \%$ DMSO. Incubation was carried out at $37{ }^{\circ} \mathrm{C}$ for 20 minutes by adding kynuramin $(50 \mu \mathrm{L} /$ well $)$ and enzyme solution $(50 \mu \mathrm{L} /$ well) to the microplates. At the end of this period, $75 \mu \mathrm{L} /$ well of $2 \mathrm{~N} \mathrm{NaOH}$ solution was used to terminate the reaction between MAO enzymes and kynuramin. Fluorescence values of wells were read at 310/380 (excitation / emission) $\mathrm{nm}$ with the help of microplate reader and $\mathrm{IC}_{50}$ values of the compounds were calculated [15-18].

\section{RESULT AND DISCUSSION}

\section{A. Chemistry}

In this study, we have synthesized new compounds, which possessed benzimidazole-propargyl moiety. The synthetic pathway was outlined in Figure-2. Firstly, 2-Chloro-1-(prop-2-yn-1-yl)-1H-benzo[d]imidazole (1) were obtained by reaction between 2-chlorobenzimidazole and propargyl bromide. Finally, target compounds (2a-2c) were obtained with the reaction between compounds 1 and benzyl amine derivatives. The final compounds were purified and their structures were characterized using spectroscopic methods (1H-NMR, 13CNMR and HRMS). The ${ }^{1} \mathrm{H}-\mathrm{NMR}$ spectra of compounds showed signals at 2.24-5.25 ppm for aliphatic protons. 
$\mathrm{N}-\mathrm{H}$ had peaks between $7.01 \mathrm{ppm}$ and $7.03 \mathrm{ppm}$ as triplet. In the ${ }^{13} \mathrm{C}$ NMR spectrum, aliphatic peaks belonging to substituents were observed between $31.04 \mathrm{ppm}$ and $79.20 \mathrm{ppm}$. Aromatic carbons were gained between $102.95 \mathrm{ppm}$ and $159.16 \mathrm{ppm}$. All masses were accorded with the estimated $\mathrm{M}+\mathrm{H}$ values.

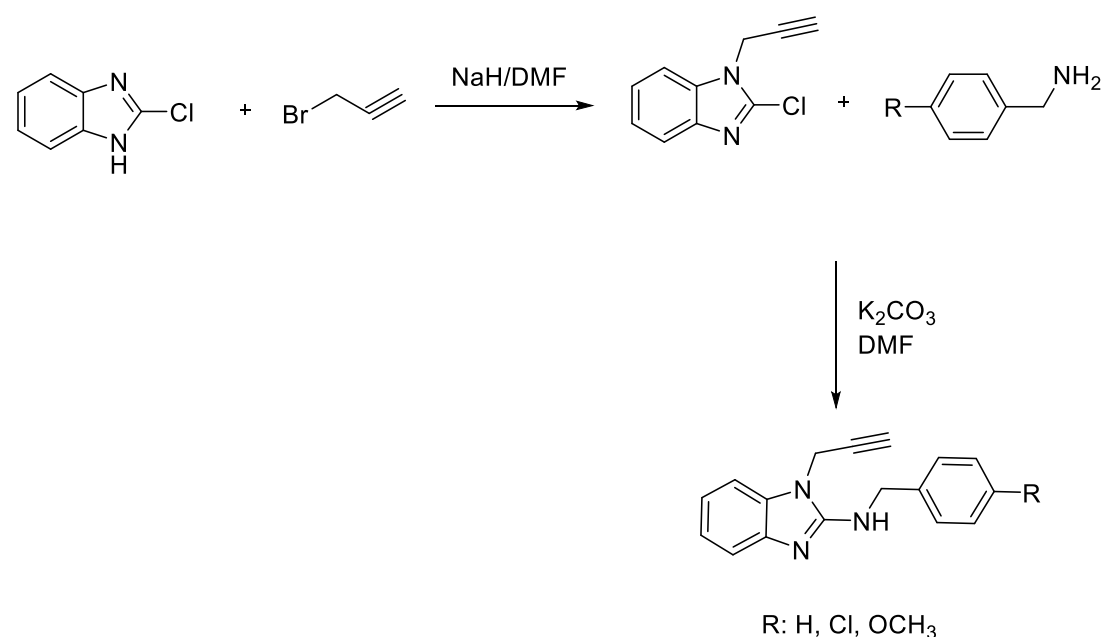

Figure 2. The Synthetic Pathway of the Compounds.

\section{B. MAO Inhibitory Assay}

In vitro studies were conducted to evaluate the $h \mathrm{MAO}-\mathrm{A}$ and $h \mathrm{MAO}-\mathrm{B}$ inhibitory activities of the compounds obtained. Selegiline and Moclobemide were used as reference compounds. The results obtained as \% inhibition are presented in Table 1. In the context of in vitro activity studies, synthesized compounds were prepared at concentrations of $10^{-3}$ and $10^{-4} \mathrm{M}$, and the inhibition values of MAO A and MAO B were calculated.

Within the scope of this study, 3 compounds were synthesized, the benzimidazole-propargyl derivative. The effects of the resulting compounds on MAO-A and MAO-B enzymes were investigated by in vitro fluorimetric method. As a result of the activity studies, it has been determined that the compounds have lower activity potential compared to MAO-A reference drug moclobemide and MAO-B reference drug selegiline. It has a promising activity profile with $71 \%$ inhibition level, which is compound $2 \mathrm{c}$ among the compounds. At the same time, the effect results show that the variable groups in the structure contribute to the activity. The higher activity potential of the compounds on the MAO-B enzyme reveals the selectivity of the propargyl group on this enzyme. Some of the clinically prescribed MAOi drugs such as rasagiline and selegiline, are already known to carry the propargyl group in their chemical structures $[19,20]$.

Generally, the compounds showed higher activity against $h \mathrm{MAO}-\mathrm{B}$ than $h \mathrm{MAO}-\mathrm{A}$. The selective compounds against the MAO-B enzyme prove the affinity of the propargyl group to the MAO-B enzyme. The effects of propargil group on MAO enzymes have been revealed in literature studies. This group interacts with the Phe208 amino acid in the active site. And it has been found to be more active against MAO-B [21-24]. In particular compounds $2 \mathrm{~b}$ and $2 \mathrm{c}$ have a significant activity value against $h \mathrm{MAO}-\mathrm{B}$. Compounds $2 \mathrm{~b}$ showed inhibition against $h \mathrm{MAO}-\mathrm{B}$ with values of $\% 61.75$ at $1 \mathrm{mM}$ concentration. Compounds $2 \mathrm{c}$ showed inhibition against $h$ MAO-B with values of $\% 71.12$ at $1 \mathrm{mM}$ concentration. It appears that the phenyl ring being nonsubstituted does not contribute to the activity. The substitution from the 4th position increases the activity. When the structures of these compounds are examined, it is seen that they carry electron donoring group such as chloride and methoxy. The most active derivative, the compound $2 \mathrm{c}$, inhibits the enzyme MAO-B by $71.12 \%$ at a concentration of $1 \mathrm{mM}$, while inhibiting the enzyme MAO-A by $31.85 \%$. In other words, it is approximately 2 times more selective against MAO-B enzyme. This rate is similar to that of selegiline. 


\begin{tabular}{|c|c|c|}
\hline & $\begin{array}{l}\text { BŞEÜ Fen Bilimleri Dergisi } \\
7(2), 755-763,2020\end{array}$ & $\begin{array}{r}\text { BSEU Journal of Science } \\
\text { DOI: } 10.35193 / \text { bseufbd. } 681580\end{array}$ \\
\hline & & 58-7575 (http://dergipark.gov.tr/bseufbd) \\
\hline
\end{tabular}

\begin{tabular}{|c|c|c|c|c|c|}
\hline \multirow[t]{2}{*}{ Compounds } & \multirow[t]{2}{*}{$\mathbf{R}$} & \multicolumn{2}{|c|}{$\begin{array}{l}\text { \% MAO-A } \\
\text { Enzyme } \\
\text { Inhibition }\end{array}$} & \multicolumn{2}{|c|}{$\begin{array}{l}\text { \% MAO-B } \\
\text { Enzyme } \\
\text { Inhibition }\end{array}$} \\
\hline & & $\begin{array}{c}\mathbf{0 . 1} \\
\mathrm{mM} \\
\end{array}$ & $1 \mathrm{mM}$ & $\begin{array}{c}\mathbf{0 . 1} \\
\mathrm{mM} \\
\end{array}$ & $1 \mathrm{mM}$ \\
\hline $2 \mathbf{a}$ & $-\mathrm{H}$ & 19.31 & 34.29 & 46.63 & 55.27 \\
\hline $2 b$ & $-\mathrm{Cl}$ & 24.65 & 32.44 & 52.44 & 61.75 \\
\hline $2 c$ & $-\mathrm{OCH}_{3}$ & 26.19 & 31.85 & 63.54 & 71.12 \\
\hline Selegiline & - & 33.16 & 39.71 & 88.96 & 95.29 \\
\hline Moclobemide & - & 68.14 & 81.23 & 18.61 & 23.09 \\
\hline
\end{tabular}

\section{CONCLUSION}

Within the scope of this study, 3 compounds have been synthesized from benzimidazole-propargyl derivative. ${ }^{1} \mathrm{H}$ and ${ }^{13} \mathrm{CNMR}$ spectroscopy help was clarified about the structures of the compounds obtained. The effects of the resulting compounds on MAO-A and MAO-B enzymes were investigated by the in vitro fluorimetric method. As a result of the activity studies, it was determined that the compounds have a lower activity potential compared to reference drugs. However, compound $\mathbf{2 c}$ has a promising activity profile with $71.12 \%$ inhibition levels. In addition, the activity results show that variable groups in the structure contribute to the activity. The fact that the compounds have higher activity potential on the MAO-B enzyme reveals the effect of the propargyl group on this enzyme. These study results are shining light for future studies. In the light of the results obtained, the activity of the new compounds is interesting by changing the benzylamine residue. In addition, the fact that the benzimidazole ring is aromatic and the propargyl group in the compound of the selegiline is connected to an aliphatic structure overlap with each other. It is believed that the activity will increase in compounds where the propargyl amine group is less affected by the steric barrier. Additionally, the presence of an electron donor group in the benzylamine substituent increases the activity against the MAOs enzyme. The highest activity value is in the compound bearing the methoxy substituent. Compared to the chlorine atom, the electronegativity difference of the oxygen atom may have revealed this activity change.

\section{REFERENCE}

[1] Zindo, F. T., Malan, S. F., Omoruyi, S. I., Enogieru, A. B., Ekpo, O. E., Joubert, J. (2019). Design, synthesis and evaluation of pentacycloundecane and hexacycloundecane propargylamine derivatives as multifunctional neuroprotective agents. European journal of medicinal chemistry, 163, 83-94.

[2] Kumar, B., Kumar, V., Prashar, V., Saini, S., Dwivedi, A. R., Bajaj, B., Mehta, D., Parkash, J., Kumar, V. (2019). Dipropargyl substituted diphenylpyrimidines as dual inhibitors of monoamine oxidase and acetylcholinesterase. European journal of medicinal chemistry, 177, 221-234.

[3] Sasidharan, R., Baek, S. C., Leelabaiamma, M. S., Kim, H., Mathew, B. (2018). Imidazole bearing chalcones as a new class of monoamine oxidase inhibitors. Biomedicine \& Pharmacotherapy, 106, 8-13.

[4] Szökö, É., Tábi, T., Riederer, P., Vécsei, L., Magyar, K. (2018). Pharmacological aspects of the neuroprotective effects of irreversible MAO-B inhibitors, selegiline and rasagiline, in Parkinson's disease. Journal of Neural Transmission, 125(11), 1735-1749.

[5] Zhou, S., Chen, G., \& Huang, G. (2018). Design, synthesis and biological evaluation of lazabemide derivatives as inhibitors of monoamine oxidase. Bioorganic \& medicinal chemistry, 26(17), 4863-4870.

[6] Finberg, J. P. (2019). Inhibitors of MAO-B and COMT: Their effects on brain dopamine levels and uses in Parkinson's disease. Journal of Neural Transmission, 126(4), 433-448. 
[7] Kumar, B., Kumar, M., Dwivedi, A. R., Kumar, V. (2018). Synthesis, Biological Evaluation and Molecular Modeling Studies of Propargyl-Containing 2, 4, 6-Trisubstituted Pyrimidine Derivatives as Potential Anti-Parkinson Agents. ChemMedChem, 13(7), 705-712.

[8] Mathew, B., Parambi, D. G., Mathew, G. E., Uddin, M. S., Inasu, S. T., Kim, H., Marathakam, A., Unnikrishnan, M., Carradori, S. (2019). Emerging therapeutic potentials of dual-acting MAO and AChE inhibitors in Alzheimer's and Parkinson's diseases. Archiv der Pharmazie, 352(11), 1900177.

[9] Tripathi, R. K. P., Ayyannan, S. R. (2019). Monoamine oxidase-B inhibitors as potential neurotherapeutic agents: An overview and update. Medicinal research reviews, 39(5), 1603-1706.

[10] Cakmur, R. (2011). Parkinson hastalığı ve medikal tedavisi. Klinik Gelişim, 53-58.

[11] Demirkiran, M., Jankovic, J. (1995). Paroxysmal dyskinesias: clinical features and classification. Annals of Neurology: Official Journal of the American Neurological Association and the Child Neurology Society, 38(4), 571-579.

[12] Uzbay, T. (2007). Nöropsikofarmakoloji: Rasyonel ilaç kullanımı. Medikal Yayıncılık, İstanbul, 110-115.

[13] Kayaalp, O. (2005). Rasyonel Tedavi Yönünden Tıbbi Farmakoloji. Hacettepe Taş Yayınları, Ankara, 913918.

[14] Mancuso, R., Veltri, L., Russo, P., Grasso, G., Cuocci, C., Romeo, R., Gabriele, B. (2018). Palladiumcatalyzed carbonylative synthesis of functionalized benzimidazopyrimidinones. Synthesis, 50(02), 267-277.

[15] Can, Ö. D., Osmaniye, D., Özkay, Ü. D., Sağlık, B. N., Levent, S., Ilgın, S., Baysal, M., Özkay, Y., Kaplancikl1, Z. A. (2017). MAO enzymes inhibitory activity of new benzimidazole derivatives including hydrazone and propargyl side chains. European journal of medicinal chemistry, 131, 92-106.

[16] Can, N. Ö., Osmaniye, D., Levent, S., Sağlık, B. N., Korkut, B., Atlı, Ö., Özkay, Y., Kaplancıklı, Z. A. (2018). Design, synthesis and biological assessment of new thiazolylhydrazine derivatives as selective and reversible hMAO-A inhibitors. European journal of medicinal chemistry, 144, 68-81.

[17] Ilgın, S., Osmaniye, D., Levent, S., Sağlık, B. N., Acar Çevik, U., Çavuşoğlu, B. K., Özkay, Y., Kaplanciklı, Z. A. (2017). Design and synthesis of new benzothiazole compounds as selective hMAO-B inhibitors. Molecules, 22(12), 2187.

[18] Sağlık, B. N., Çavuşoğlu, B. K., Osmaniye, D., Levent, S., Çevik, U. A., Ilgın, S., Özkay, Y., Kaplancıklı, Z.A., Öztürk, Y. (2019). In vitro and in silico evaluation of new thiazole compounds as monoamine oxidase inhibitors. Bioorganic chemistry, 85, 97-108.

[19] Youdim, M. B., Gross, A., \& Finberg, J. P. (2001). Rasagiline [N-propargyl-1R (+)-aminoindan], a selective and potent inhibitor of mitochondrial monoamine oxidase B. British journal of pharmacology, 132(2), 500-506.

[20] Knudsen Gerber, D. (2011). Selegiline and rasagiline: twins or distant cousins? Guidelines. The Consultant Pharmacist ${ }^{\circledR}, 26(1), 48-51$.

[21] Chioua, M., González-Camuñas, A., Catarozzo, M. T., Alcaro, S., Ortuso, F., Yáñez, M., Marco-Contelles, J. (2019). Synthesis, Monoamine Oxidase Inhibition and Computational Analysis of Diversely Substituted N-Propargylated-1, 3, 5-triazines. ChemistrySelect, 4(28), 8334-8337.

[22] Knez, D., Colettis, N., Iacovino, L. G., Sova, M., Pislar, A., Konc, J., Lesnik, S., Higgs, J., Kamecki, F., Mangialavori, I., Dolsak, A., Zakelj, S., Tronteli, J., Kos, J., Binda, C., Marder, M., Dolsak, A. (2020). Stereoselective Activity of 1-Propargyl-4-styrylpiperidine-like Analogues That Can Discriminate between Monoamine Oxidase Isoforms A and B. Journal of Medicinal Chemistry, 63(3), 1361-1387. 
[23] Kumar, B., Kumar, M., Dwivedi, A. R., Kumar, V. (2018). Synthesis, Biological Evaluation and Molecular Modeling Studies of Propargyl-Containing 2, 4, 6-Trisubstituted Pyrimidine Derivatives as Potential Anti-Parkinson Agents. ChemMedChem, 13(7), 705-712.

[24] Nag, S., Kettschau, G., Heinrich, T., Varrone, A., Lehmann, L., Gulyas, B., Thiele, A., Keller, E., Halldin, C. (2013). Synthesis and biological evaluation of novel propargyl amines as potential fluorine-18 labeled radioligands for detection of MAO-B activity. Bioorganic \& medicinal chemistry, 21(1), 186-195. 